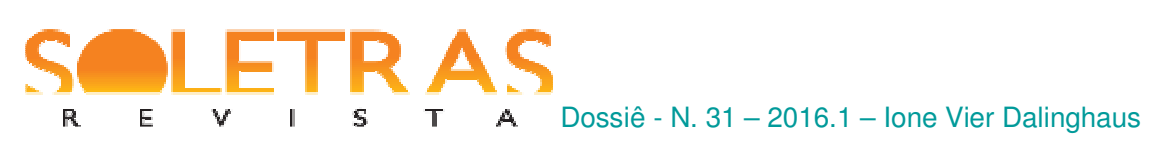

\title{
Estudo da descortesia como estratégia de persuasão em um debate político entre José Serra e Fernando Haddad
}

\author{
Ione Vier Dalinghaus ${ }^{1}$
}

Universidade Federal de Mato Grosso do Sul

\begin{abstract}
Resumo: Este artigo insere-se no âmbito das pesquisas linguístico-discursivas de interações face a face. Selecionou-se, como objeto de estudo, o debate realizado pelo SBT- Sistema Brasileiro de Televisão e UOL - Universo Online, exibido por ocasião do segundo turno entre os candidatos a prefeito de São Paulo, Fernando Haddad (PT) e José Serra (PSDB), nas eleições de 2012. A análise, à luz da semiótica francesa (GREIMAS \& COURTÈS, 1979; BARROS, 2003), ancorou-se também nos estudos de descortesia, especialmente em Blas Arroyo (2001) e Silva (2013). Pretende-se mostrar, por meio dela, como as estratégias linguísticas de manipulação são utilizadas em ambientes conflituosos. Observa-se que, no debate político televisivo, a interação é trílogue (KERBRAT-ORECCHIONI, 2006), pois além do mediador e dos debatedores, há o público telespectador, principal alvo do programa. Considerando o real objetivo do debate político - a conquista do voto -, a tendência dos candidatos é buscar a autopromoção, lançando mão de estratégias de autovalorização em detrimento da desqualificação do candidato oponente. Focalizaram-se, neste estudo, as estratégias descorteses dos políticos, no intuito de identificar o procedimento persuasivo mais utilizado e evidenciar que a descortesia tem importante função no discurso, fortalecendo-se como um novo campo de estudos no quadro da teoria geral do discurso. A pesquisa confirmou ser a provocação a estratégia de manipulação mais recorrente no corpus analisado.
\end{abstract}

Palavras-chave: Debate político. Descortesia. Manipulação.

\section{Considerações iniciais}

Este artigo insere-se no âmbito dos estudos linguístico-discursivos, focalizando uma interação face a face em um debate eleitoral televisivo. Selecionou-se como objeto de análise para este estudo o debate eleitoral promovido e organizado pelo SBT - Sistema Brasileiro de Televisão em parceria com a UOL - Universo Online, por ocasião do $2^{\circ}$ turno das eleições à prefeitura municipal de São Paulo em 2012, entre os candidatos José Serra (PSDB) e Fernando Haddad (PT). Para a análise, fez-se uso também do vídeo correspondente ao conteúdo transcrito, cujo material completo está disponível online ${ }^{2}$.

1 Graduada em Letras Habilitação Português /Espanhol pela UEMS; especialista em Língua e Literatura de Expressão Hispânica pela UNIDERP, Mestre em Letras pela UNIOESTE; doutoranda pelo Programa de PósGraduação em Letras UPM-MACKENZIE e professora efetiva do Curso de graduação em Letras Português/Espanhol na UFMS, de Aquidauana, MS. E-mail: ioneufms@gmail.com.

2 Vídeos e transcrições disponíveis em: http://www1.folha.uol.com.br/poder/2012/10/1174668-leia-atranscricao-completa-do-debate-sbtuol-entre-haddad-e-serra.shtml. Acesso em 16 de abril de 2014. 
Trata-se, portanto, de uma tripla interação (quando há três ou mais interações verbais), instalando-se, assim, o que Kerbrat-Orecchioni (2006) denomina quadro participativo. Este se caracteriza pela interação entre os dois candidatos convidados, entre cada um destes debatedores e o mediador Carlos Nascimento, entre este e o público telespectador e, entre os candidatos e o público. Este último é o principal enunciatário deste tipo de programa eleitoral, pois a finalidade dos políticos é conquistar os votos dos eleitores. Os organizadores do debate também têm como foco principal os telespectadores, uma vez que a finalidade do programa é o esclarecimento da opinião pública, propiciando aos eleitores a oportunidade de conhecer melhor os candidatos, seus planos de governo e suas aspirações. Este estudo parte do enunciado que, "por oposição à enunciação, deve ser concebido como o estado que dela resulta, independentemente de suas dimensões sintagmáticas" (GREIMAS E COURTÈS, 1979, p.124). Focaliza-se especialmente em um dos quatro tipos de persuasão sugeridos pela teoria de Greimas (1998), a provocação.

O que se pretende é mostrar como os procedimentos de provocação podem funcionar como estratégias de persuasão no debate político, em que os debatedores têm a oportunidade de desconstruir a imagem do seu adversário e construir a sua autoimagem positiva. Tais manifestações nem sempre são consideradas descorteses, uma vez que, no tipo de interação “debate político", não se espera que os candidatos sejam corteses entre si. Em outras palavras, os atos provocativos e irônicos são considerados lícitos, desde que não ultrapassem os limites do contrato comunicativo ${ }^{3}$ estabelecido entre os interlocutores. Assim, é percebido como descortês o candidato que desrespeitar as regras pré-estabelecidas pelo mediador. Entendemse como transgressões os insultos, eventuais agressões físicas ou verbais que possam atingir a integridade moral do candidato adversário.

É pertinente lembrar que as provocações podem ocorrer de forma implícita ou explícita, gerando diferentes efeitos na construção do sentido. Os procedimentos atenuadores, quando acompanhados de ironia ou de outros recursos que mascarem a ameaça para preservar a própria imagem, são considerados descorteses. Frequentemente os candidatos preferem recorrer a este tipo de estratégia (aparentemente menos ofensiva) a atacar explicitamente a face negativa do adversário, pois tal atitude poderia comprometer a sua imagem pública.

3 “[...] toda troca linguageira se realiza num quadro de co-intencionalidade, cuja garantia são as restrições da situação de comunicação. O necessário reconhecimento recíproco das restrições da situação pelos parceiros da troca linguageira nos leva a dizer que estão ligados por uma espécie de acordo prévio sobre os dados desse quadro de referência (CHARAUDEAU, 2006, p. 68).

SOLETRAS - Revista do Departamento de Letras da FFP/UERJ

Número 31 (jan.-jun. 2016)

ISSN: 2316-8838

DOI: $10.12957 /$ Soletras.2016.24769 
Assim, é bastante comum entre os debatedores ressaltar suas próprias qualidades, no intuito de desviar a atenção dos telespectadores para os defeitos do candidato adversário.

No intuito de mostrar como ocorrem tais manifestações no debate político televisivo escolhido como objeto de análise, o presente artigo vem ancorado nas teorias da cortesia/descortesia (KERBRAT-ORECCHIONI, 2006; BLAS ARROYO, 2011; SILVA, 2013) e da Semiótica Francesa, especialmente Barros (2003; 2008; 2012).

\section{Linguagem e interação: uma breve reflexão sobre a construção da imagem}

Inicia-se esta seção lembrando que é na prática social que a linguagem significa, sendo este, por conseguinte, "o seu caráter primordial, sua vocação original que transcende e explica todas as funções que ela assegura no meio humano" (BENVENISTE, 2006, p. 222). Assim, é por meio das análises dos eventos discursivos formais ou informais, que o homem se torna um objeto de estudo. Ressalta-se que os estudos da linguagem e do discurso oferecem a possibilidade de se conhecer o homem, a história e a sociedade, através de uma nova perspectiva, a perspectiva interacional.

Nas interações humanas, a tendência é a busca do equilíbrio entre os interlocutores, utilizando-se para isso, estratégias de cortesia para valorizar e preservar a face do interlocutor e, consequentemente, a sua autoimagem. A teoria da face se originou em Goffman (1970) e continua sendo o ponto de referência para os estudos interacionais. O autor define face (imagem) como:

[...] um valor social positivo que uma pessoa efetivamente reivindica para si mesma através da linha que os outros pressupõem que ela assumiu durante um contato particular. A [face] é uma imagem do eu delineada em termos de atributos sociais aprovados [...] (GOFFMAN, 2012, p. 13).

A noção de face apresentada por Goffman equivale à imagem e contempla as dimensões do individual e do social. É, portanto, a imagem pública do indivíduo, o valor social positivo que o (EU), como indivíduo relacionado com os demais indivíduos da sociedade deseja para si. É justamente em função da preservação da face que enunciador/destinador e enunciatário/destinatário costumam tratar-se de forma cordial e amigável. No entanto, quando se trata de um debate eleitoral em que o alvo maior é o público telespectador, é para esses interlocutores que os candidatos voltam a sua atenção. Utilizando-se de procedimentos que contribuam para desqualificar o candidato oponente e, ao mesmo tempo, preservar a própria 
face, os debatedores tentam conquistar os seus eleitores. É a partir desse facework (trabalho da face), ou seja, do desempenho dos oradores que emerge o seu éthos.

Cabe informar que a primeira noção de éthos surgiu com Aristóteles, embora o filósofo grego não tenha utilizado explicitamente o referido termo. Este apareceu bem mais tarde, na teoria polifônica da Enunciação (DUCROT, 1984, p. 201), para quem o éthos "está ligado ao locutor como tal; é como origem da enunciação que ele se vê investido de certos caracteres que, em contrapartida, tornam essa enunciação aceitável ou recusável”. Contudo, atribui-se a Dominique Maingueneau (2005, p.31) a elaboração da noção de éthos como construção de uma imagem de si no discurso:

O que o orador pretende ser, ele o dá a entender e mostra; não diz que é simples ou honesto, mostra-o por sua maneira de se exprimir. O éthos está, dessa maneira, vinculado ao exercício da palavra, ao papel que corresponde a seu discurso. E não ao indivíduo "real", (apreendido) independentemente de seu desempenho oratório; é, portanto, sujeito da enunciação.

Portanto, o éthos não corresponde ao caráter do orador, mas ao que ele demonstra ser. Assevera Maingueneau (1995) que, na construção da imagem, o que é dito e a maneira de dizê-lo são igualmente importantes e indissociáveis. O que fica implícito no discurso do orador também contribui na configuração do seu éthos.

Frequentemente, no intuito de conquistar o voto dos eleitores, os políticos fazem promessas exageradas. Isto representa um risco aos enunciadores, caso os eleitores percebam que tais promessas não poderiam ser cumpridas. Da mesma forma, os procedimentos de autovalorização da face nem sempre são eficientes no discurso político. Por sua prepotência, o candidato pode perder a face (GOFFMAN, 1970).

\section{O discurso político e a mídia}

A mídia é o canal pelo qual o discurso político contemporâneo encontra maior espaço para aproximar-se à grande massa do eleitorado. É principalmente por este canal que os eleitores acessam aos programas políticos e decidem seu voto. O discurso político é, portanto, um lugar de argumentação, um discurso orientado para a persuasão. Pode-se dizer então que o debate político é, por natureza, dialógico e que nele prevalece a competição discursiva, que consiste na troca de ideias que têm como objetivo maior vencer, convencendo.

Assim, mesmo não participando diretamente do debate, os eleitores são a razão pela qual o programa é produzido e levado ao ar. Goffman (1970) compara esse tipo de interação 
a uma cena teatral, uma vez que os "atores" representam para a audiência, sempre em detrimento da imagem do oponente. O discurso político tem, por isso, características próprias, pois a vitória ou a derrota do candidato dependem do poder de argumentação do enunciador. Se os eleitores não estiverem preparados para interpretar e desvendar o que está implícito no dito, correm o risco de equivocar-se em suas conclusões e julgamentos.

Para Charaudeau (2013, p.08), o discurso político é, “[...] por excelência, o lugar de um jogo de máscaras". Essas máscaras, segundo o autor, correspondem às diferentes identidades: “[...] várias máscaras são possíveis e, portanto, várias identidades são possíveis”. Em decorrência disso, o autor recomenda que quando se trata de discurso político, cada palavra pronunciada seja analisada pelo dito e também pelo não dito, isto é, pelo explícito e pelo que pode estar subentendido no discurso.

Diante da complexidade intrínseca ao discurso político, especialmente quando se trata de um programa como o debate com fins eleitorais, o ideal seria que o pesquisador analisasse não só os materiais verbais, mas também os materiais paraverbais e não verbais, termos que Kerbrat-Oreccioni (2006, p. 36-37) explicita, resumidamente, da seguinte forma:

- Material verbal: conjunto de unidades que derivam da língua (unidades fonológicas, lexicais e morfossintáticas);

- Material paraverbal (prosódico e vocal): entonações, pausas, intensidade articulatória, elocução, particularidades da pronúncia, características da voz;

- Material não verbal: não são transmitidas pelo canal visual, mas distinguem-se pelos signos. a) estáticos: tudo o que constitui a aparência física dos participantes; b) cinéticos lentos: distâncias, atitudes e posturas; c) cinéticos rápidos: mímicas, gestos, jogos dos olhares.

Assim, é a partir do conjunto desses materiais que o analista consegue identificar, descrever e interpretar os procedimentos utilizados por cada candidato. Cada detalhe observado oferece ao pesquisador um elemento a mais que pode contribuir para resultados mais precisos na análise.

\section{A persuasão sob a perspectiva da Semiótica}

Além de examinar qualquer tipo de texto verbal, escrito ou visual, a Semiótica de origem francesa volta-se também para a comparação dos enunciados analisados. Examina-se, 
por um lado, a enunciação como organização sintática narrativa, o sujeito da enunciação e, por outro lado, a enunciação em um conjunto de textos. Estudam-se as ações na narrativa, as manipulações que ocorrem entre enunciador e enunciatário e também, as sanções que ocorrem em função de determinadas ações. Convém lembrar que até recentemente, a Semiótica era voltada especialmente ao texto, contudo tem ampliado seu foco de análise para a enunciação, por entender que é na interação entre os interlocutores que se constitui o verdadeiro sentido do enunciado.

As estratégias da persuasão analisadas neste trabalho inserem-se na sintaxe narrativa em que se caracteriza o sujeito por seu modo de agir, pois "ao contrário do que ocorre nas relações entre máquinas, na comunicação entre os homens, os sujeitos envolvidos não são lugares vazios e sim, casas cheias" (BARROS, 2012, p. 28). Ao fazer tal afirmação, a autora se refere aos valores, projetos, aspirações, desejos e às diferentes maneiras de ver e de interpretar o mundo. Afirma a linguista que, com base nesses elementos, procura-se, em toda relação de comunicação, convencer o outro de alguma coisa, persuadi-lo, levá-lo a acreditar em algo, a experimentar algo e a fazer o que se quer que ele faça. Estabelece-se assim, um contrato fiduciário entre enunciador e enunciatário, cabendo ao primeiro exercer o fazer persuasivo, a partir de estratégias destinadas a este fim, no intuito de convencer o enunciatário a aceitar e agir de acordo com suas crenças e valores. Ao segundo, cabe realizar o fazer interpretativo e, a partir deste, aceitar ou rejeitar o contrato proposto pelo enunciador.

No entanto, as estratégias variam de acordo com o público, a sociedade e a época em que o discurso persuasivo acontece. Quanto a este aspecto vale lembrar que, no debate político, uma estratégia bastante utilizada pelo enunciador é a provocação, que consiste em apresentar imagens negativas do destinatário e de sua competência. A tentação se caracteriza por apresentar valores que o destinador julga serem almejados pelo destinatário. Já a intimidação, implica em chantagem emocional, ou seja, o destinador apresenta valores que o destinatário possivelmente teme ou tenta evitar.

Reforça-se que a interação pode ser cooperativa ou de conflito. Dependendo das estratégias usadas pelo destinador ou enunciador, criam-se efeitos de objetividade ou de subjetividade, gerando assim maior proximidade ou maior distanciamento em relação ao destinatário ou enunciatário. Tudo depende, portanto, de como é projetado o enunciado, se é em primeira ou em terceira pessoa. Em decorrência dessa escolha, bem como do tempo e do espaço da enunciação, tem-se uma enunciação enunciada ou um enunciado enunciado (FIORIN, 2002). 
Os efeitos de cortesia/descortesia são gerados de acordo com os procedimentos utilizados pelos enunciadores, levando-se em conta os fatores culturais e contextuais da interação. É pertinente lembrar que tanto a cortesia como a descortesia "pertencem aos campos semânticos da civilidade e da urbanidade, ou do modo de se comportar na sociedade." (BARROS, 2008, p. 93). Os procedimentos corteses são, portanto, aqueles que contribuem para o equilíbrio na interação, isto é, a conduta esperada em determinados contextos sociais. Já a descortesia é gerada por procedimentos contrários ao equilíbrio na conversa, desrespeitando-se o contrato comunicativo, podendo tornar-se regra quando a intenção é justamente denegrir, desvalorizar e ofender o interlocutor. Os atos descorteses, em qualquer situação, são interpretados como enfrentamento intencional.

$\mathrm{Na}$ disputa pelo voto, a tendência dos enunciadores que participam de um debate político é a utilização de estratégias de autovalorização em detrimento da desqualificação do candidato oponente. Assim, "é comum que haja não a preservação da própria imagem, mas a autopromoção" (SILVA, 2013, p. 105). Formulam-se contrastes desvantajosos em relação ao adversário, na intenção de persuadir os eleitores. As denúncias infundadas também fazem parte do grupo de manifestações estratégicas para "denegrir a imagem do oponente". Elas adquirem mais força ainda quando o locutor atribui a outrem a responsabilidade, isentando-se do que foi dito sobre o adversário político.

Feitas essas considerações, procede-se à análise e interpretação do corpus, o debate político televisivo de segundo turno realizado pelo SBT e UOL nas eleições para a prefeitura de São Paulo, em outubro de 2012, disputadas por Fernando Haddad e José Serra.

\section{Análise e interpretação do corpus}

Conforme a proposta anunciada na introdução deste trabalho pretendeu-se identificar as diferentes estratégias de persuasão utilizadas nos discursos proferidos pelos candidatos. Notese que se analisaram apenas os recursos linguísticos, não por considerar menos importantes os recursos extralinguísticos, mas porque a limitação de páginas desta publicação não permite uma análise exaustiva do objeto. Assim, recorreu-se aos vídeos apenas para sanar algumas dúvidas sobre a presença de ironia ou outras estratégias de manipulação não linguísticas.

Nesta breve análise, examinar-se-ão apenas os excertos em que mais aparecem estratégias de persuasão (a tentação, a intimidação, a sedução e a provocação). Esta última parece ser a estratégia de manipulação mais frequente nos debates políticos, talvez porque "a 
provocação funciona melhor no espaço público, pois, dessa forma, o provocado sente-se obrigado a reagir à provocação, para mostrar à sociedade que os traços negativos que lhe foram atribuídos são indevidos" (BARROS, 2008, p. 93).

No intuito de situar o leitor no contexto do debate que nos serve de corpus neste trabalho, reproduzimos parte da fala inicial do mediador Carlos Nascimento:

Você vai acompanhar a partir de agora o debate entre os candidatos que vão disputar o segundo turno da eleição para Prefeitura da cidade de São Paulo. Uma iniciativa e também uma inovação do jornalismo do SBT e do portal UOL que trazem pela primeira vez um debate político para as seis horas da tarde, o que certamente vai permitir que seja acompanhado por um número muito maior de eleitores. [...].

Conforme anunciado anteriormente, o debate em análise foi ao ar no dia 24 de outubro de 2012, às 18 horas, ao vivo e dividido em três blocos. Ressalta-se que, antes de pleitear o cargo, Serra já havia sido prefeito e governador de São Paulo pelo PSDB - Partido da Social Democracia Brasileira. Nas eleições de 2012, venceu no primeiro turno, mas foi derrotado no segundo turno pelo ex-ministro da Educação, Fernando Haddad do PT - Partido dos Trabalhadores.

Após essas considerações, passa-se à análise da descortesia identificada no corpus desta pesquisa. Considerando que grande parte dos atos normalmente considerados descorteses são lícitos nos debates políticos, dadas as características deste tipo de evento discursivo, foram considerados descorteses apenas os atos praticados intencionalmente para provocar o adversário. Os enunciados analisados foram destacados, sequencialmente enumerados e identificados pelo sobrenome dos debatedores.

Entre os temas polêmicos abordados neste debate, destacam-se alguns como: segurança, habitação e meio-ambiente. Para falar sobre o primeiro, o candidato José Serra enfatiza os cargos anteriormente ocupados por ele e tenta convencer os eleitores sobre as melhorias ocorridas em seu governo.

(01) Serra: Já fui prefeito e já fui governador, já tive a responsabilidade também sobre a segurança. A situação de segurança em São Paulo deixa a desejar, é insatisfatória, mas é preciso considerar que melhorou muito comparativamente ao resto do Brasil. Inclusive Estados administrados pelo PT, como é o caso da Bahia. [...] São Paulo é o que registrou a maior queda de homicídios no Brasil proporcionalmente em termos absolutos nos últimos 12, 13 anos. Agora, a prefeitura pode fazer coisas importantes nessa direção. Uma delas é reforçar a Operação Delegada, que o PM na hora de folga é contratado para a prefeitura. Hoje já tem 8 mil PMs nesse programa e 4 mil na rua. [...] Enfim, são questões que podem em ser bastante melhoradas mediante a intensificação da cooperação da prefeitura com o governo do Estado. Entre eu, prefeito, e o Alckmin, governador. 
Procedimentos como esse, de "sedução por intensificação", são frequentemente utilizados para acentuar críticas e discordâncias do destinador em relação ao destinatário. Tal recurso permite a construção da imagem positiva do falante, enquanto é gerada uma imagem de incompetência do candidato oponente. Os candidatos se utilizam da sedução no intuito de ganhar mais credibilidade junto ao público eleitor.

O candidato do PSDB menciona, neste primeiro excerto, dados estatísticos sobre a segurança em São Paulo e garante contar com o apoio do governador Alkmin para novos avanços neste setor. Sabe-se que este é um forte argumento, uma vez que os recursos para as prefeituras dependem, em grande parte, dos governos Estadual e Federal.

Com as atitudes acima mencionadas, Serra tenta construir o seu éthos de credibilidade, ou seja, a sua imagem positiva de homem público competente, confiável e que tem, portanto, condições de governar o município de São Paulo. Ao proferir um discurso político, o sujeito constrói para si, por meio de estratégias cuidadosamente selecionadas, uma figura daquele que enuncia. Essa imagem construída pelo orador pode gerar, ao olhar do outro, uma identidade psicológica e social que Charaudeau (2013) denomina éthos. O éthos é a fusão dessa dupla identidade, ou seja, aquela que o enunciador tenta construir e mostrar, e aquela que o enunciatário lhe atribui.

Assim, "Identidades discursiva e social fusionam-se no éthos". Para o autor, a partir das figuras identitárias do discurso político, os ethé podem ser classificados em dois tipos: os ethé de credibilidade - ligados à razão e que são constituídos pelo éthos de 'sério', éthos de 'virtude' e éthos de 'competência' -, e os ethé de identificação, ligados ao afeto e que surgem a partir do éthos da 'potência', do 'caráter', da 'inteligência', de 'humanidade', de 'chefe', e de 'solidariedade' (CHARAUDEAU, 2013, p.113-166).

Na tentativa de desconstruir a argumentação do candidato oponente, Haddad defende-se apresentando novos dados e, dessa maneira, provoca Serra, acusando-o de fugir à discussão e à responsabilidade.

(02) Haddad: Serra, os dados recentes sobre violência dão conta de que o problema é muito mais grave e mais recente do que você imagina. Não estou falando de coisa de doze, quinze anos atrás. Estou falando de agora, do presente e do futuro, o que você às vezes reluta em discutir. O homicídio doloso aumentou $15 \%$ do ano passado para cá, dados oficiais da secretaria de segurança. Número de vítimas aumentou 17\%. Tentativa de homicídio, 35\%. Estupro, 26\%. E latrocínio, 6\%. [...] sua proposta não é para segurança, sua proposta é para coibir o comércio irregular. O que você pretende fazer?

Por meio de sua argumentação, Haddad busca em seu discurso o éthos de credibilidade pautado em três condições, a saber: a seriedade, o autocontrole (diante das críticas e da vida 
privada e a virtude) e da competência. Respondendo à provocação do adversário, Serra joga parte da responsabilidade ao governo Federal e alega que os dados mencionados por Serra não são reais. Implicitamente, o adversário político é tachado de mentiroso, utilizando-se para isso, a estratégia de sedução por atenuação que costuma ser usada "para apresentar, de forma negativa, o modo de ser e de agir do destinatário" (BARROS, 2008, p. 94).

A crítica de Serra, transcrita abaixo, reflete duplamente sobre Haddad, haja vista ser ele o representante do PT, partido do Governo Federal e por ser desafiado pelo candidato oponente quanto à questão da segurança.

(03) Serra: Eu respondi sobre segurança, candidato Haddad, e você não disse nada sobre segurança, exceto citar números, tirando de contexto. A segurança em São Paulo não está piorando do ponto de vista global, tal como seus dados sugerem, pelo contrário, a tendência ao declínio da gravidade continua, embora o problema seja grave. [...] Nós temos que ser pragmáticos e concretos nessa matéria. Mais ainda, o governo federal tem uma enorme responsabilidade nessa área, porque não combate o tráfico de drogas nem o contrabando, que estão na base da prosperidade do crime, não só em São Paulo como em todo o Brasil.

Em relação à temática focada ao meio-ambiente, José Serra exibe números relativos à quantidade de parques existentes na cidade de São Paulo, comparando-os com o quantitativo de área verde existente antes de assumir a prefeitura em 2005. A estratégia utilizada é novamente a da intensificação.

(04) Serra: Fernando, eu queria saber qual é o seu projeto para a área de verde, de parques em São Paulo. Quando eu assumi a Prefeitura, em 2005, tinha 34 parques, hoje tem 85. Ou seja, muito mais do dobro daqueles que foram deixados pela administração do PT, pela Prefeitura da qual você participou. Eu queria saber qual é o seu programa nessa área para parques na cidade. Agora, a curto prazo, e ao longo de todo o mandato.

Utilizando-se da atenuação linguística “eu queria saber”, o candidato do PSDB tenta desmascarar o petista, perante os eleitores, tentando fortalecer a sua própria imagem. $\mathrm{O}$ emprego do verbo no futuro do pretérito do indicativo é considerado, na teoria da cortesia, uma forma polida de dirigir-se ao interlocutor. Porém, no contexto em pauta, não fica difícil perceber que a atitude de Serra não passa de mais uma provocação ao candidato concorrente. Haddad defende-se primeiramente, da acusação anterior (excerto 03), dizendo que se utilizou de dados oficiais e que, ao contrário de Serra, se eleito, não atribuirá ao Governo Federal uma responsabilidade que é de competência do prefeito municipal.

(05) Haddad: Em primeiro lugar gostaria de dizer que os dados que eu relatei são dados oficiais da secretaria de segurança, é o acumulado de janeiro a agosto. Nós temos esse problema de escalada da violência de um ano para cá. E o José Serra, candidato José Serra, prefere atribuir a responsabilidade ao governo federal, e não assumir as responsabilidades da prefeitura e do governo estadual, pelo que está acontecendo. Eu não, eu prefiro assumir as responsabilidades de candidato a prefeito, que quando prefeito assumirá compromisso com a população na área da segurança.

SOLETRAS - Revista do Departamento de Letras da FFP/UERJ

Número 31 (jan.-jun. 2016)

ISSN: 2316-8838

DOI: $10.12957 /$ Soletras.2016.24769 
Quando o foco da discussão se volta para o setor habitacional, novos dados são apresentados por Haddad, no intuito de convencer o eleitor de que houve um crescimento bem mais significativo nas gestões anteriores a Serra.

(06) Haddad: E esta administração tem o pior indicador na área de habitação, mesmo levando em conta os dados do candidato Serra, 28 mil moradias em oito anos, é a pior marca registrada, são 3500 moradias por ano, e contra 5700 da gestão Marta e 9 mil da gestão Erundina, nove mil da gestão Erundina. Além do mais, nós temos que considerar este absurdo que foi a criação da taxa da inspeção veicular que eu pretendo acabar.

Entende-se que a apresentação de dados concretos revela mais uma tentativa do candidato petista na construção do seu éthos de credibilidade. A resposta de Serra é feita em tom irônico:

(07) Serra: Fernando, sabe uma coisa que eu tenho inveja de você, inveja mesmo, a capacidade de fugir das questões, a capacidade de não dizer nada. Eu perguntei sobre parques na cidade. Aparentemente você não tem ideia do assunto, parque é uma coisa importante para o meioambiente, para o lazer, para o esporte, para as famílias. Encontramos 34 parques. Hoje tem 84. Até o fim do ano terá 100 e vou fazer na minha gestão de prefeito, se for escolhido, que eu espero mais 50 parques na cidade. Isso é muito bom para o meio-ambiente.

Volta à pauta a questão do meio-ambiente, mais especificamente, à construção de parques verdes. Ao repetir a informação "nove mil da gestão Erundina", o candidato Serra intensifica uma característica negativa do partido adversário e, após acusá-lo de não ter conhecimento dos fatos e de esquivar-se das perguntas, o candidato do PSDB aproveita para expor seus planos em relação ao setor, se eleito. Portanto, tenta enaltecer a própria imagem em detrimento da desconstrução da imagem de Haddad. A provocação irônica é respondida por Haddad com outra provocação, desta vez desqualificando Serra. O candidato é ridicularizado pelo petista diante dos telespectadores:

(08) Haddad: Você percebe a falta de conexão que o candidato não faz em relação a questão social e ambiental, ele não consegue perceber que a melhoria da condição de urbanização da cidade, de construção de moradia popular, é o que vai abrir espaço na cidade para cidade respirar. A cidade respira quando você tem coleta seletiva e temos a pior marca também da gestão Serra/Kassab, $1 \%$ do lixo reciclado, e quando você tem praticamente metade do esgoto da cidade não é tratado. Embora você, cidadão, pague por isso para a Sabesp. Então conectar essas coisas é que é grave. O que você chama de parque é muito diferente do que eu chamo de parque. O que você chama de parque são praças, muitas vezes, e estão mal cuidadas [...].

Além de insistir na desqualificação do candidato oponente, por confundir praças com parques e por não fazer a coleta seletiva do lixo, Haddad se coloca no mesmo patamar dos eleitores almejando o éthos de identificação. Para ganhar a credibilidade dos eleitores, faz questão de lembrar que quem vai pagar o prejuízo consequente da falta de reciclagem e esgoto na cidade são os cidadãos, nos quais ele se inclui.

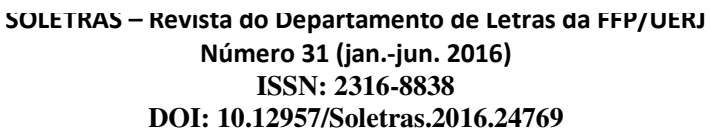


No excerto seguinte, Haddad pressiona Serra a explicar-se sobre questões polêmicas em que este estaria envolvido, especialmente a cobrança de pedágio:

(09) Haddad: Serra, você tem defendido algumas ideias muito polêmicas, a taxa da controlar, taxa de inspeção veicular, defendeu uma lei estadual que está suspensa pela Justiça, do tribunal, de venda de leitos de hospitais públicos e privados da Cidade de São Paulo. E queria saber se você defende outra ideia polêmica, que é pedagiar as estradas.

A estratégia aplicada por Fernando Haddad pode ser classificada como uma provocação explícita. Antes de responder ao questionamento, Serra acusa seu oponente de alicerçar sua campanha sobre especulações e volta à questão do meio-ambiente, acusando o PT de não ter uma proposta de governo nesse setor.

(10) Serra: O governo do Estado não tem essa ideia polêmica, isso foram especulações, e na época da campanha o seu partido e vocês aproveitaram para fazer proselitismo com essa história. Deixa eu voltar um tópico antes. É uma questão de natureza social. [...] O que eu verifico é que não tem proposta. Você não apresenta, o PT não tem propostas nessa área, até porque praticamente não fez nada.

Em seguida, faz referência ao pagamento de impostos e menciona uma taxa de asfaltamento, conhecida como "Martaxa" cobrada pelo PT e que teria sido retirada pelo governo do PSDB. Ressalta que, além de diminuir os impostos, durante o seu governo foi criada a Nota Fiscal Paulista. Conclui seu turno de fala utilizando-se novamente da sedução por atenuação explícita, ao afirmar que o PT nada fez durante os quatro anos de governo.

(11) Serra: Quanto à questão de taxas, a que você se refere, na verdade, o Fernando Haddad foi o guru, o orientador da Marta nessa matéria, que ficou chamada Martaxa, que criou, e mais ainda, o candidato foi a câmara de vereadores para defender. Existiu uma taxa de asfalto, sempre tenho curiosidade, uma taxa de asfalto para ruas de terra que a população tinha que pagar, eles não tiraram esta taxa, nós tiramos. Se alguém entende de diminuir e aliviar impostos, é este que está falando, sou eu. Inclusive fizemos a Nota Fiscal Paulista e a Nota Fiscal Paulistana, pela primeira vez, não na história de São Paulo, do Brasil, se devolve impostos para o bolso. [...] pergunto o que é que foi que a administração do PT fez ao longo dos seus quatro anos? Nada em São Paulo.

Como resposta, Haddad volta a falar sobre moradias, enfatizando que os dados por ele apresentados são de fonte segura e não inventados pelo seu partido, conforme estaria insinuando o seu adversário. Também acusa Serra de cobrar pedágios, prejudicando com isso a população carente de São Paulo. Ora, sabe-se que ao dirigir-se à camada mais pobre, implicitamente o candidato tenta convencer os eleitores de que ele, ao contrário de Serra, vai trabalhar em prol dos carentes.

(12) Haddad: Dados oficiais da secretaria de habitação, 3500 moradias por ano na gestão Serra/Kassab. Serra, você não respondeu minha pergunta. O jornal Folha de São Paulo, não é o PT que inventa essas coisas. O jornal Folha de São Paulo estampou na capa do jornal que o governo pretendia pedagiar por quilômetro percorrido, e não da maneira como é hoje, isso vai acarretar prejuízo para a população pobre de São Paulo, porque muita gente para chegar em 
Perus, Itaim Paulista, São Miguel, passa por rodovias estaduais. E se nós pedagiamos no espaço urbano, vai encarecer ainda mais a vida do morador da preferia. [...] como fizeram com o Rodoanel, prometeram não pedagear e pedagiaram.

Desta vez, Serra faz sua defesa por meio da ironia explícita, dizendo que Haddad está mal assessorado e desconhece os problemas referentes ao município de São Paulo.

(13) Serra: Esta questão do pedágio dentro da cidade não existe, como eu acho que o Fernando Haddad não é mentiroso, ele está sendo mal assessorado, ele não conhece os problemas diretamente, não tem muito conhecimento a respeito da cidade. [...]. Quanto a ação de moradia, foram 28 mil moradias, sem contar as obras da CDHU, do Governo do Estado, quando eu dirigia, mas tem mais, nós fizemos o maior trabalho da história de transformações de favelas em bairros. [...].

Ao dizer que Haddad "não é mentiroso", mas está "mal assessorado", Serra tenta proteger a própria face. O termo mal assessorado é menos ofensivo que o termo mentiroso. É pertinente lembrar que evitar a descortesia explícita faz parte das estratégias que protegem o enunciador. Ainda no mesmo enunciado, Serra retoma a polêmica do setor habitacional elogiando seu próprio governo. Trata-se de um procedimento bastante utilizado pelos políticos, pois se ataca a face do oponente com vistas à autoconstrução da imagem positiva.

Ao responder a pergunta feita por Serra em relação ao programa cultural, Fernando Haddad volta a atacar seu adversário, apresentando dados numéricos de forma irônica. $\mathrm{O}$ objetivo é provar ao eleitor que o candidato oponente não cumpriu a sua meta enquanto prefeito de São Paulo:

(14) Haddad: Serra, eu sei que você não liga para a questão social, é do teu perfil desconsiderar esta questão, por isso que você desconecta a questão ambiental da questão social. Divida 28 por 8, Serra, você vai encontrar 3500 casas por ano, eu estou seguindo o teu número e dividindo pelos oito anos que vocês governaram a cidade. Matemática você entende, entende bem, divida 28 por 8 e vai chegar no número que eu apresentei. [...]. Você mesmo não consegue citar no seu programa, estamos há 60 dias em campanha e você não cita uma única parceria que você deseja fazer com o governo federal.

Serra, por sua vez, insiste em acusar Haddad de se esquivar da resposta e reforça a provocação anterior, afirmando novamente que o governo petista nada fez em termos de melhorias sociais:

(15) Serra: Como sempre, desculpe a insistência, não respondeu à pergunta. O hábito petista, $e$ o seu, Fernando, me desculpe a franqueza, tem que ver a questão social primeiro, etc., tal, e não tem nenhuma proposta. A questão social fica esvaziada. O PT não fez nada em matéria de desenvolvimento e urbanização de favelas. Nada.

Quando o assunto é corrupção, o debate se torna ainda mais polêmico, com acusações diversas por parte de ambos os candidatos, numa descortesia escancarada. Observe, por 
exemplo, os excertos (16 a 19), em que Serra acusa o PT de usar o governo como propriedade privada e de participar de esquemas polêmicos como o Mensalão.

Por sua vez, Haddad se defende das acusações, de forma irônica, desqualificando Serra como homem desrespeitoso, que espalha rumores e boatos em relação ao possível fechamento de creches e que esconde fatos graves como, por exemplo, o desvio da merenda escolar.

Nos fragmentos abaixo se identificaram diferentes formas de manipulação, em ameaças diretas e indiretas, numa clara disputa pelos votos. Apontar as falhas do adversário e de seu partido, bem como acusá-lo de corrupto são práticas bastante comuns nos debates políticos.

(16) Serra [...] por falar em corrupção, eu acho que é interessante também lembrar em relação à cidade de São Paulo, que a prefeita Marta, a administração Marta, tem hoje mais de 70 processos na justiça, problemas de todos os tipos. Esta é uma questão séria dentro da cidade, que em parte isso vinha também daquela frouxidão, mas falando em corrupção no Brasil não podemos deixar de mencionar hoje a questão do mensalão. Isso não é nem processo, não é nem suspeita não, é condenação. A cúpula do PT, a cúpula do Partido dos Trabalhadores durante tanto tempo foi condenada, formação de quadrilha. [...].

(17) - Haddad: Serra, o teu desrespeito chega às raias da insanidade, trazer mensalão para cá? Do que você está falando? Você me conhece o suficientemente para fazer que eu tenho doze anos de vida pública, 30 anos de vida acadêmica, que tenho uma reputação ilibada, não há sequer uma suspeita, à frente do Ministério da Educação, onde eu administrei [...].

(18) Serra: [...] o método petista é de usar o governo como se fosse propriedade privada, fizeram isso no passado, inclusive aqui em São Paulo, inclusive na prefeitura, fizeram isso no governo federal, de onde o Fernando Haddad vem, se ele não esteve envolvido diretamente no mensalão, ele está envolvido com o partido que fez o mensalão. Isso que é importante.

(19) Haddad: Quem anda falando muito é você, Serra. Você resolveu agora espalhar rumores e boatos na cidade de São Paulo, chegou a afirmar que eu vou fechar creches conveniadas quando fui eu que introduzi no FUNDEB as creches públicas e conveniadas, uma lei sancionada pelo presidente Lula com a minha assinatura. [...] Agora, no que diz respeito às filas, você há de convir comigo, o trabalho vem sendo malfeito, e o prontuário eletrônico não existe na Cidade de São Paulo, e mais do que isso, não há transparência dos dados de fila de saúde na cidade de São Paulo. [...] O candidato Serra acha que a saúde vai muito bem. Ele foi eleito prefeito, renunciou, um ano depois, mas disse o seguinte, se despreocupem porque a minha equipe permanece. [...] O secretário de Saúde respondendo por desvio de merenda, de criança! Contudo ele se manteve no cargo porque o procedimento aqui é diferente. No governo federal se apura e se pune, aqui é para baixo do tapete.

Cabe ressaltar que a manipulação somente é bem sucedida "quando o sistema de valores em que ela está assentada for compartilhado pelo manipulador e pelo manipulado, quando houver certa cumplicidade entre eles" (BARROS, 2003, p. 33). A autora pontua ainda que "Não se deixar manipular é recusar-se a participar do jogo do destinador [...]".

Na discussão do tema "A Cracolândia" prevalecem as acusações diretas, explícitas, numa provocação mútua em que cada qual quer sair vantajoso. É o que se pode observar nos exemplos (20 a 27): 
(20) Haddad: A presidenta Dilma tinha recém lançado um programa de combate ao crack, Crack é Possível Vencer, mas o governo desconsiderou a proposta de parceria e meteu os pés pelas mãos com uma operação que disseminou o crack pela cidade de São Paulo.

(21) José Serra: Se é para falar de governo federal, o governo federal liberou apenas $8 \%$ do seu orçamento para o Brasil inteiro voltado a recuperação de dependentes químicos, não fez praticamente nada [...] O PT em oito anos de prefeitura não fez nada, no governo federal não fez nada, nós fizemos e vamos fazer mais.

(22) Haddad: Olha, Serra, em recente entrevista na CBN você disse o que ia fazer para combater o crack e assustou toda a população. Para monitorar quem tem propensão a consumir drogas. Você falou isso na CBN, circulou em todas as redes sociais, foi matéria de jornal. Serra, eu pergunto, onde é que você estava com a cabeça quando você propôs isso? [...].

(23) Serra: [...] é absolutamente falsa aquilo que o candidato Haddad disse sobre uma entrevista minha à CBN a respeito de violência nas 19:08 escolas, a pergunta foi do que eu faria em relação a violência nas escolas. [...] É uma infâmia, a palavra crack nem foi mencionada por mim. A rede petista pegou isso para espalhar calúnia como costuma fazer com muitas outras questões.

(24) Haddad: O seu desconhecimento em relação a São Paulo é grande, em relação ao Brasil eu já desconhecia, você chamou o Brasil de Estados Unidos do Brasil num dia desses, misturou o nome do seu próprio país, que você pretendeu presidir por duas vezes, foi constituinte, assinou a constituição e não sabia o nome do seu próprio país. [...]. Não consigo compreender sua resposta [...] Você viu que eu perguntei sobre enchente, ele me falou de um tal de "Bilhete Amigão", ninguém sabe o que é, eu perguntei de moradia, ele não respondeu. Eu estou com dados da secretaria de habitação, dados oficiais, mas já que ele respondeu outra coisa, o que tem enchente com ensino técnico no contexto em que eu perguntei?

(25) Serra: Quando a gente ouve calúnia [...], a gente tem que usar o tempo para poder respondê-la. Na questão específica da pergunta que eu deixei para responder agora, eu quero dizer o seguinte, há mais de dois anos não tem vítimas por enchente em São Paulo. [...].

(26) Haddad: Repare que o candidato Serra está sempre se referindo a administrações passadas, nunca olhando para o futuro, nunca fazendo a divisão entre o que eles fizeram em oito anos e o que ele pretende fazer em quatro. Eu fiz uma proposta muito concreta, não é o uso da bicicleta por trinta minutos não, você vai ter três horas para usar a bicicleta para chegar a um terminal de transferência ou a uma estação de trem e de metrô.

(27) Serra: O Fernando Haddad, o próprio Lula, procuraram o Kassab para pedir apoio na Prefeitura, como não os apoiou, virou capeta para eles. O PT é assim, o PT, quando tem um aliado, esse aliado é santo, pode ser o Collor, Maluf, pode ser quem for, quando está contra, aí é o diabo. Assim que atua na política.

Nos últimos turnos de fala os candidatos se despedem dos eleitores pedindo votos, desta vez, de forma explícita. Ambos se autoelogiam em relação ao desempenho na campanha, construindo, para si, uma imagem explícita positiva e, por oposição, uma imagem negativa para o destinatário, isto é, o candidato oponente. Os candidatos aproveitam para reforçar as promessas anteriormente feitas e, apesar de todos os atos de descortesia durante o debate, 
Haddad se autodefine como um político seguro de suas propostas, alguém que sabe respeitar o candidato adversário, enquanto Serra diz estar com sua consciência e ficha limpas, por atuar com ética e honestidade.

(28) Haddad: Fiz até aqui uma campanha propositiva, fui o primeiro candidato a apresentar um plano de governo com metas, [...] Sempre fiz propostas, nunca ofendi ninguém, nunca ofendi o prefeito Kassab, nunca ofendi o candidato José Serra. Discuti a gestão.

(29) Serra: [...] eu me apresentarei, como tenho me apresentado, de cabeça erguida, com orgulho de ser candidato a prefeito da minha cidade e com a consciência tranquila. Toda vida eu me dediquei a causa pública numa perspectiva: resolver problemas econômicos sociais, e fiz isso ao longo da minha vida, com ficha limpa, ou seja, combinando realização com passado limpo, que é uma questão fundamental, inclusive para a cidade.

Ao fechar o seu discurso, Serra utiliza-se do advérbio negativo "não", objetivando gerar um efeito contrário. Trata-se de um procedimento de intensificação, construção explícita da sua própria imagem positiva em detrimento da imagem negativa do oponente. Observe-se que todas as ações mencionadas por Serra são ações que este atribui ao outro candidato, como negativas, enquanto tenta construir a autoimagem de homem público comprometido com a ética e a honestidade.

(30) Serra: não vou governar para patotas, para partidos, para grupos, não vou lotear a máquina da Prefeitura, não vai ter desempregado de mensalão no meu governo, aqueles que foram condenados não vão ter influência, não vai ter ninguém que ficou sem emprego porque foi condenado que virá para a Prefeitura porque eu considero essa questão da ética fundamental, nós não podemos deixá-la de lado, é realização com ética, com honestidade, com moral.

\section{Considerações finais}

Apresentados e analisados os trinta excertos retirados da transcrição do último debate de segundo turno à prefeitura municipal de São Paulo, conclui-se que as diferentes estratégias de descortesia utilizadas pelos debatedores criam, de fato, efeitos de sentido capazes de desvalorizar ou desconstruir a imagem do destinatário e, por consequência, enaltecer a imagem positiva do destinador.

No debate político eleitoral, os interlocutores costumam preferir o desacordo, pois o que de fato lhes interessa não é o adversário político, o interlocutor direto, mas sim, a conquista dos eleitores que assistem ao programa. Assim, o debate político representa um grande instrumento nas campanhas políticas e está sempre focado no público eleitor. Por essa razão, muitas vezes, a descortesia aparece dissimulada, para não causar a impressão de agressividade e desrespeito. 
Dentre os tipos de manipulação elencados pela Semiótica da linha francesa, prevalece, no debate analisado, a provocação. Por meio dela são apresentadas imagens negativas do destinatário. Lançando mão desse recurso, os debatedores tentam atribuir o máximo de incompetência ao candidato oponente. Se este aceitar a manipulação do destinador, sua imagem positiva será prejudicada, porém, ele pode reagir à provocação tentando provar aos telespectadores que os traços negativos a ele atribuídos são falsos e indevidos. Portanto, o êxito ou o fracasso dos candidatos dependem de como é articulada essa manipulação.

Conclui-se também, pelas transcrições analisadas, que prevalecem as provocações explícitas, geralmente respondidas com dados estatísticos, argumentos com fontes consideradas confiáveis, no intuito de "derrubar" os argumentos utilizados pelo adversário. Com isso, o debatedor fortalece o seu discurso ganhando maior credibilidade por parte do público telespectador.

Finalmente, pode-se dizer que os demais tipos de manipulação como a tentação, $a$ intimidação e a sedução aparecem mescladas, contudo, em quantidade bem menor. Num estudo mais minucioso, poder-se-ia destacar também tais procedimentos e verificar os efeitos de sentido por eles gerados.

Assim, este estudo tem a pretensão de somar-se a outros já publicados, no intuito de mostrar que a descortesia tem importante função no debate político e fortalece-se, cada vez mais, como um novo campo de estudos no quadro da teoria geral do discurso, especialmente na Semiótica Discursiva da Linha Francesa.

\section{Referências}

ARISTÓTELES. Arte Retórica e Arte Poética. Tradução Antônio Pinto de Carvalho. Rio de Janeiro: Ediouro, 1979.

BARROS, Diana Luz P. de. Teoria semiótica do texto. São Paulo: Ática, 2003.

Estudos do discurso. In: José Luiz Fiorin. (Org.). Introdução à Linguística: princípios de análise. 3. ed. São Paulo: Contexto, 2005, v. 1, p. 187-219.

A provocação no diálogo: estudo da descortesia. In: PRETI, Dino (Org.). Cortesia verbal. São Paulo: Humanitas, 2008. p. 89- 124.

. Algumas reflexões semióticas sobre enunciação. In: DI FANTI, M.G; BARBISAN, L. B. (Orgs). Enunciação e discurso: tramas de sentidos. São Paulo: Contexto, 2012, p. 28-43.

BENVENISTE, Émile. Problemas de linguística geral II. 2. ed. Trad. Eduardo Guimarães et al. São Paulo: Pontes, 2006. 
CHARAUDEAU, P.; MAINGUENEAU, P. Dicionário de análise do discurso. São Paulo: Contexto, 2004.

CHARAUDEAU, Patrick. Discurso das mídias. São Paulo: Contexto, 2006.

Discurso político. 2 Ed. S. Paulo: Contexto, 2013.

DUCROT, Oswald. Le dire et le dit. Paris: Minuit, 1984.

PODER, 2012. Leia a transcrição completa do debate SBT/UOL entre Haddad e Serra. São Paulo, 24 out. 2012. Disponível em: <http://www1.folha.uol.com.br/poder/2012/10/1174668leia-a-transcricao-completa-do-debate-sbtuol-entre-haddad-e-serra.shtml>. Acesso em 16 de abril de 2014.

FIORIN, José Luiz. Elementos de análise do discurso. São Paulo: USP, 1992. Ática, 2002.

As astúcias da enunciação: as categorias de pessoa, espaço e tempo. São Paulo:

GOFFMAN, Ervin. Ritual de la interacción. Buenos Aires: Tiempo Contemporáneo, (1967) 1970.

Ritual de interação: ensaios sobre o comportamento face a face. Trad. Fábio Rodrigues Ribeiro da Silva Petrópolis, RJ: Vozes, 1. ed. 2012.

GREIMAS, Algirdas Julien; CORTÈS, Joseph. Sémiotique: dictionnaire raisonné de la théorie du langage. Paris, Hachette, v.1, 1979.

GREIMAS, Algirdas Julien. Sobre o sentido: Ensaios Semióticos. Petrópolis, RJ: Vozes. 1998.

KERBRAT-ORECCHIONI, Catherine. Análise da conversação: princípios e métodos. Trad. Carlos Piovezani Filho. São Paulo: Parábola, 2006.

\section{Study of discourtesy as strategy of persuation in a political debate between José Serra and Fernando Haddad}

Abstract: This paper falls within the context of the linguistic and discursive research of faceto-face interactions. The object of study selected was the discussion displayed during the second round between the candidates for mayor of São Paulo, Fernando Haddad (PT) and José Serra (PSDB), by the SBT- Brazilian Television System and UOL - Universe Online, in the 2012 elections. It is intended to show, in the light of French semiotics (GREIMÁS \& COURTÈS, 1979; BARROS, 2003) and also on discourtesy studies, especially based in Blas Arroyo (2001) and Silva (2013) the use of language strategies of manipulation in conflicting environments. It is observed that, the interaction in television political debate is a trialogue

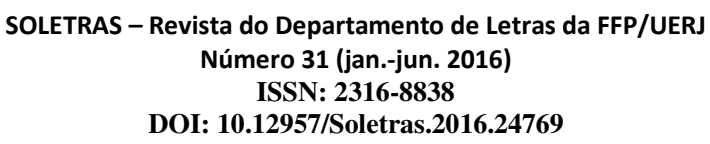


(Kerbrat-Orecchioni, 2006) interaction, because besides the mediator and debaters, there is the viewer audience, who are the main target of the program. Considering that the actual objective of the political debate - winning the vote - the tendency of the candidates is to seek self-promotion, making use of self-worth strategies to disqualify the opponent candidate.The study focuses on discourteous strategies used by the politicians aiming at identifying the most frequent persuasive procedure and showing evidence that discourtesy has an important role in discourse, which has been strengthened as a new field of studies in the general theoretical framework of discourse. The research confirmed that provocation is the most common strategy of manipulation in the analyzed corpus.

Keywords: Political debate. Discourtesy. Manipulation.

Recebido em: 07 de junho de 2016.

Aprovado em: 28 de junho de 2016. 